\title{
Erratum to: Functional Analysis of Membrane Proteins Produced by Cell-Free Translation
}

\section{Srujan Kumar Dondapati, Doreen A. Wüstenhagen, and Stefan Kubick}

\section{Erratum to:}

Chapter 10 in: Uwe T. Bornscheuer and Matthias Höhne (eds.), Protein Engineering: Methods and Protocols, Methods in Molecular Biology, vol. 1685, https://doi.org/10.1007/978-1-4939-7366-8_10

This protocol was originally published (C) Springer Science+Business Media LLC 2018, but has now been made available (C) The Author(s) under a CC BY 4.0 license. 